Nany Librianty ${ }^{1}$

\title{
Studi Tentang Peran Kepemimpinan Kepala PAUD
}

\begin{abstract}
Abstrak
Penelitian ini bertujuan untuk mengetahui gambaran peran kepala sekolah berkaitan dengan fungsi EMASLIM tersebut. Metode penelitian yang digunakan adalah deskriftif kualitatif dengan pendekatan studi kasus. Pengumpulan data dilakukan melalui wawancara dan studi dokumentasi. Data yang berhasil dikumpulkan ditriangulasi dan direduksi sehingga menghasilkan kesimpulan. Peran kepemimpinan kepala PAUD sebagai EMASLIM di PAUD Terpadu Pratiwi telah berjalan dengan baik, dengan adanya berbagai bentuk usaha menanamkan nilai-nilai positif di lingkungan sekolah, adanya tim pengembang yang dibentuk sebagai tim research and development, keikutsertaan dalam berbagai bentuk kompetisi dan pelatihan terkait peningkatan mutu dan kualitas pendidikan PAUD Terpadu Pratiwi. Selain dari pada itu dalam pengelolaan kesiswaan, sarana dan prasarana dilaksanakan secara terprogram dan terperinci sehingga kelemahan dan kekuatan dapat diinventarisir dengan baik yang memungkinkan perencanaan program ke depannya akan lebih baik.
\end{abstract}

Kata Kunci: Kepemimpinan, Lembaga PAUD, Anak Usia Dini

\begin{abstract}
This study aims to describe the role of the principal in relation to the EMASLIM function. The research method used is descriptive qualitative with a case study approach. Data collection is done through interviews and documentation studies. The data collected was triangulated and reduced so as to draw conclusions. The leadership role of the PAUD head as EMASLIM in the Pratiwi Integrated PAUD has been going well, with various forms of efforts to instill positive values in the school environment, the development team formed as a research and development team, participation in various forms of competition and training related to quality improvement and the quality of Pratiwi's Integrated PAUD education. Apart from that in the management of student affairs, facilities and infrastructure are carried out in a programmed and detailed manner so that weaknesses and strengths can be properly inventoried which will enable better planning of future programs
\end{abstract}

Keyword : EMASLIM function, leadership, early childhood

\footnotetext{
${ }^{1}$ Universitas Pahlawan Tuanku Tambusai, Riau, Indonesia

Email : nanilibria@gmail.com
}

Aulad : Journal on Early Childhood, 2019, 2(1), 9 - 17 


\section{PENDAHULUAN}

Dewasa ini muncul berbagai konsep mengenai kepemimpinan kepala sekolah yang ideal dalam memimpin lembaganya, diantaranya yaitu konsep kepala sekolah sebagai EMASLIM. EMASLIM sendiri merupakan akronim dari Educator, Manajer, Administrator, Suvervisor, Leader, Inovator dan Motivator. Dengan kata lain kepala sekolah harus memadai di segala bidang, baik secara administratif atupun dalam pengelolaan sumberdaya yang dimiliki lembaganya.

Kepemimpinan kepala sekolah menjadi suatu hal yang menarik untuk diteliti, Menurut Wahjosumidjo (2011: 81) Kepala PAUD atau TK adalah "Seseorang yang diberi tanggung jawab untuk memimpin PAUD atau TK". Dalam kondisi ini kepala sekolah dituntut memiliki kecakapan yang memadai demi kemajuan sekolah yang dipimpinnya. Begitu juga halnya dengan PAUD Terpadu Pratiwi yang merupakan salah satu lembaga Pendidikan Anak Usia Dini di Kota Bangkinang, Tingginya minat orang tua memasukan anaknya di PAUD Terpadu Pratiwi, memberikan tanggung jawab yang besar pula terhadap para pengelolanya. Selain dari tingginya minat masyarakat menyekolahkan anaknya di PAUD Terpadu Pratiwi, juga begitu banyak prestasi yang melekat di PAUD Terpadu Pratiwi yang harus dipertahankan dan mungkin harus ditingkatkan.

Di tahun 2017, PAUD Terpadu Pratiwi sudah memenangkan berbagai kejuaraan, lomba menari krasi, lomba mewarnai tingkat kecamatan, lomba membaca ayat pendek tingkat Kabupaten, lomba peragaan busana daerah tingkat Kabupaten. Menurut Ibu... Selaku Kepala PAU Pratiwi, kualitas dan prestasi siswa tersebut dihasilkan dari proses bimbingan dan belajar mengajar yang diberikan oleh guru yang memiliki dedikasi tinggi. Sebagai PAUD yang berciri khas memiliki peserta didik yang sangat aktif dalam kegiatan kreatif, inovatif, mandiri, agamis dan santun tidak heran memang jika PAUD ini akan semakin banyak menghasilkan siswa-siswi yang berkualitas. Hal ini memerlukan pemimpin yang kompeten sehingga segala hal baik yang tersemat di PAUD Terpadu Pratiwi dapat dijaga dan ditingkatkan. Penelitian ini ditujukan Untuk memperoleh gambaran yang jelas tentang ruang lingkup penelitian, yaitu bagaimana peran kepemimpinan Kepala Sekolah di PAUD Terpadu Pratiwi sesuai dengan karakter EMASLIM (Educator, Manager, Administrator, Suvervisor, Leader, Inovator dan Motivator)

Istilah EMASLIM pertama kali muncul berdasarkan Keputusan Menteri Pendidikan dan Kebudayaan Republik Indonesia No. 489 Tahun 1992 pasal 7 ayat 1 yang menyebutkan bahwa tugas dan fungsi kepala sekolah adalah sebagai educator, manajer, administrator, supervisor, leader, inovator dan motivator. Tugas dan fungsi tersebut merupakan rangkaian yang lebih spesifik di samping tugas-tugas yang lebih luas dalam totalitas kepemimpinan pada lembaga pendidikan.

Nurkolis (2003:119) menyatakan : Pada tingkat sekolah, kepala sekolah sebagai figure kunci dalam mendorong perkembangan dan kemajuan sekolah. Kepala sekolah tidak hanya meningkatkan tanggung jawab dan otoritasnya dalam program-program sekolah, kurikulum dan keputusan personel, tetapi juga memiliki tanggungjawab untuk meningkatkan akuntabilitas keberhasilan siswa dan programnya. Kepala sekolah harus pandai memimpin kelompok dalam pendelegasian tugas dan wewenang.

Dalam posisi sebagai kepala sekolah, maka kemampuan harus dapat ditonjolkan untuk memimpin sekolah, sebab dengan segala kompleksitas permasalahan yang dihadapinya, kepala sekolah dituntut memiliki kemampuan profesiaonalisme yang lengkap. Wahjusumidjo (2003:81) menyatakan bahwa Kepala sekolah yang berhasil apabila mereka memahami keberadaan sekolah sebagai organisasi yang kompleks dan 
unik, serta mampu melaksanakan peranan kepala sekolah sebagai seseorang yang diberi tanggung jawab dalam memimpin sekolah.

Dari pengertian diatas memiliki pengertian bahwa organisasi yang kompleks yaitu organisasi yang didalamnya terdapat berbagai dimensi yang saling berkaitan dan menentukan, sedangkan unik adalah bentuk organisasi yang berbeda dengan organisasi lainnya dengan ciri-ciri yang tidak dimiliki organisasi lainnya diantaranya yaitu adanya proses belajar mengajar dan tempat mewariskan nilai-nilai serta kebudayaan.

Sebagaimana disebutkan terdahulu, tugas dan fungsi kepala sekolah bersifat kompleks. Selain itu kepala sekolah harus memiliki visi dan misi dalam memimpin sekolahnya yang harus bisa di aktualisasikan dalam kehidupan organisasinya. Dalam mewujudkan semua itu kepala sekolah memiliki tugas yaitu sebagai berikut :

1. Edukator, yaitu kepala sekolah berperan sebagai seorang pendidik baik bagi tenaga kependidikan yang ada disekolah maupun para peserta didik.

2. Manajer, yaitu kepala sekolah harus mampu memanajemen segala sumber daya yang ada di sekolah dalam pencapaian visi dan misinya.

3. Administrator, yaitu kepala sekolah harus mampu melakukan administrasi di bidang pendidikan di sekolahnya.

4. Supervisor, yaitu kepal sekolah harus bisa memberikan supervisi terhadap bawahannya dalam hal pelaksanaan pendelegasian tugas dan wewenang di sekolahnya.

5. Leader, yaitu kepala sekolah harus menjadi pemimpin yang baik bagi bawahnnya, yang mampu mengembangkan jiwa kepemimpinan sehingga mampu menjadi contoh atau teladan bagi bawahnnya.

6. Inovator, yaitu kepala sekolah harus mampu memberikan inovasi dalam menyesuaikan sekolahnya dengan perkembangan ilmu pengetahuan dan tuntutan zaman.

7. Motivator, yaitu kepala sekolah mampu memberikan dorongan terhadap seluruh elemen organisasi sekolah dalam meningkatkan kinerja dan pencapaian tujuan dari visi misi sekolah.

\section{METODE PENELITIAN}

Metode penelitian yang digunakan adalah metode deskriftif. Penelitian deskriptif adalah suatu penelitian yang dilakukan dengan tujuan utama untuk memberikan gambaran atau deskripsi tentang suatu keadaan secara objektif. Menurut Sukmadinata (2011:22), penelitian deskriptif ditujukan untuk mendeskripsikan atau menggambarkan fenomena-fenomena yang ada, baik fenomena yang bersifat alamiah atau rekayasa manusia.

Objek dalam penelitian ini adalah kepemimpinan Kepala PAUD Terpadu Pratiwi di Kota Bangkinang dan manajemen yang dilaksanakan di PAUD Terpadu Pratiwi. Kepemimpinan kepala sekolah diukur dengan berbagai indikator mulai dari kuikulum, administrasi, pengorganisasian, pelimpahan wewenang hingga pada penetapan standar kemampuan yang diterapkan berdasarkan kebijakan kepala PAUD Terpadu Pratiwi.

Untuk mendapatkan informan kunci yang tepat sesuai dengan fokus penelitian, maka informan diambil berdasarkan perposive sampling (pengambilan sampel sesuai kebutuhan). Menurut Sugiyono (2008:85) teknik sampling purposive yaitu "teknik penentuan sampel dengan pertimbangan tertentu". Teknik ini bisa diartikan sebagai suatu proses pengambilan sampel dengan menentukan terlebih dahulu jumlah sampel yang hendak diambil, kemudian pemilihan sampel dilakukan dengan berdasarkan tujuan-tujuan tertentu, asalkan tidak menyimpang dari ciri-ciri sampel yang ditetapkan. Sumber informasi dalam penelitian diambil baik dari data primer maupun sekunder. 
Sumber Informasi Kunci (Key Informan), yaitu Kepala sekolah dan Sumber Informasi Penunjang (Supportive Informan ), yang terdiri dari guru, komite sekolah.

Sumber data dalam penelitian ini adalah Kepala PAUD Terapdu Pratiwi dan guru di lingkunga PAUD Terpadu Pratiwi. Pelaksanaan pengumpulan data penelitian ini dilakukan dengan metode :

1. Wawancara, Observasi (Observation), yaitu melakukan pengamatan secara langsung terhadap aktivitas keseharian, lingkungan dan sarana kerja yang berhubungan dengan penulisan ini

2. Penelitian Kepustakaan (Library Research), Data diperoleh dengan cara membaca literatur-literatur, bahan referensi, bahan kuliah, dan hasil penelitian lainnya yang ada hubungannya dengan obyek yang diteliti. Hal ini dilakukan penulis untuk mendapatkan tambahan pengetahuan mengenai masalah yang sedang dibahasnya.

Data yang diperoleh dari berbagai sumber dalam penelitian kualitatif dapat menggunakan teknik pengumpulan data yang bermacam-macam (triangulasi) dan dilakukan secara terus-enerus sampai datanya jenuh (dapat disimpulkan). Pengamatan yang terus-menerus menghasilkan variasi data yang tinggi. Oleh karena itu sering mengalami kesulitan dalam proses menganalisanya. Analisis data kualitatif adalah bersifat induktif, yaitu suatu analisis berdasarkan data yang diperoleh selanjutnya dikembangkan pola hubungan tertentu atau menjadi hipotesis (Sugiyono,2010:335).

Penelitian ini dilaksanakan di PAUD Terpadu Pratiwi Koata Bangkinang. Waktu penelitian dilakasanakan antara bulan Januari sampai dengan Mei 2018 .

\section{HASIL PENELITIAN DAN PEMBAHASAN}

Hasil penelitian menunjukan bahwa terdapat fungsi-fungsi edukasi yang diterapkan oleh kepala PAUD Terpadu Pratiwi diantaranya yaitu dengan memberi contoh kepada bawahnnya untuk memiliki mental disiplin dan memberi dukungan pada kegiatan-kegiatan yang mampu membangun mental warga sekolah, seperti keikutsertaan sekolah dalam perlombaan-perlombaan baik secara lokal atau regional. Kepala sekolah juga berusaha menanamkan nilai-nilai moral positif baik secara adat budaya maupun secara religi. Sedangkan dalam hubungannya dengan menanamkan nilai fisik kepala sekolah berusaha menerapkan hidup sehat meski sedikit sulit, hal tersebut dilakukan lebih kepada bentuk pendekatan personal. Lebih lanjut keterliabtan dan peran serta kepala ekolah dalam menanamkan nilai seni dan budaya terlihat dari adanya dukungan terhadap nilai seni dan keindahan, juga terhadap budaya lokal yang berkembang. Dukungan tersebut berupa kegiatan-kegiatan yang mengedepankan adat budaya lokal, seperti pentas seni tradisional dalam pelepasan murid yang telah tamat, atau kegiatan ekstrakulikuler.

Tampaknya dalam hubungan dengan pemaknaan terhadap bimbingan tersebut tidak dapat dilepaskan dari pengertian pembimbingan yang dikemukakan oleh Ki Hajar Dewantara dalam sistem amongnya. Tiga kalimat padat yang terkenal dalam sistem among tersebut adalah ing ngarso sung tulodo, ing madyo mangun karsa, dan tut wuri handayani. Ketiga kalimat tersebut mempunyai arti bahwa pendidikan harus dapat memberi contoh, harus dapat memberikan pengaruh, dan harus dapat mengendalikan peserta anak didiknya. Hal ini tergambar dari sikap kepala PAUD Terpadu Pratiwi yang memberikan keteladanan, bimbingan dan pengarahan serta himbauan dalam melaksanakan tugas dan fungsinya sebagai pimpinan di lingkungan PAUD Terpadu Pratiwi. Jadi secara garis besar kepala PAUD Terpadu Pratiwi sudah melaksanakan fungsinya sebagai educator yang mengedepankan nilai mental, nilai moral, nilai fisik dan nilai artistik.

Aulad : Journal on Early Childhood, 2019, 2(1), 9 - 17 
Lebih lanjut hal tersebut merupakan strategi kepala sekolah dalam mengenalkan PAUD Terpadu Pratiwi kepada masyarakat, misalkan dengan adanya keterlibatan dalam berbagai kompetisi, selain meningkatkan nilai mental hal tersebut juga meningkatkan daya saing dan pengalaman. Selain itu dengan adanya budaya religi yang dilestarikan memberikan nilai tambah sebagai suatu lembaga pendidikan.

Sebagai seorang manajer, kepala sekolah harus mampu megelola seluruh sumber daya yang ada di sekolah, berkaitan dengan hal tersebut kepala sekolah PAUD Terpadu Pertiwi melakukan manajerial terhadap pengembangan sekolah dengan dibentuknya tim khusus. Hal tersebut dalam rangka mencapai tujuan pendidikan yang diprogramkan dan pelaksanaanya tidak lepas dari legitimasi, pengawasan dan pengarahan dari kepala sekolah,

Kepala Sekolah PAUD Terpadu Pertiwi mewujudkannya dalam pengorganisasian personal sekolah secara terstruktur dan berdaya guna disesuaikan dengan kemampuan personal. Selain itu kepala sekolah PAUD Terpadu Pertiwi juga melihat latar belakang pendidikan dan pengalaman dalam pengorganisasian personal sekolah, dengan harapan adanya kesesuain tupoksi dengan kemampuan personal. Lebih lanjut hasil penelitian menyatakan bahwa seluruh kegiatan pengorganisasin tersebut direncanakan secara terperinci, diarahkan dan dievaluasi pelaksanaanya secara berkala.

Jadi dapat disimpulkan bahwa secara garis besar fungsi manajer sudah dilaksanakan dan berjalan dengan baik di PAUD Terpadu Pertiwi dengan adanya pengorganisasian personal, evaluasi, pengarahan dan pola penugasan yang diprioritaskan sesuai dengan kemampuan personal terkait dengan pengembangan sekolah yang menjadi tujuan program sekolah. Dengan demikian maka kepala sekolah PAUD Terpadu Pratiwi telah berfungsi sebagai manajer sesuai dengan kaidah yang berlaku. Selain itu dengan adanya penetapan upaya pengembangan dengan dibentuknya tim khusus, merupakan suatu bukti nyata bahwa dengan kemampuan seorang manajer kepala PAUD Terpadu Pratiwi memiliki perhatian khusus terhadap pengembangan PAUD Tepadu Pratiwi, atau dengan mengikutsertakan guru-guru dalam pelatihan sehingga kualitas mutu pendidikan PAUD Terpadu Pratiwi dapat terjaga bahkan ditingkatkan.

Sebagai seorang administrator kepala PAUD Terpadu Pratiwi dapat dikatakan telah memenuhi criteria tersebut, meski pada pelaksanaanya lebih cenderung mendelegasikan tugas administrasinya kepada wakil yang ditunjuk, meski demikian kepala Sekolah tetap memberikan pengawasan dan pengarahan atas pelimpahan tugas dan tanggung jawab tersebut. Jadi meski tugas keadministrasian dilimpahkan kepada para bawahannya dengan adanya pengawasan dan pengarahan menunjukan kemampuan kepala sekolah sebagai seorang adaministrator, karena tanpa kemampuan administrasi yang baik pengawasan dan pengarahan masalah keadministrasian tidak akan berjalan dengan baik.

Dari hasil penelitian yang menunjukan adanya pengelolaan sistem informasi sekolah yang dibuat terintegrasi antar bagian, meski untuk sistem informasi yang sifatnya lebih luas (untuk masyarakat umum atau pihak diluar sekolah masih terkesan konvensional) dan adanya pengelolaan sumber daya sekolah baik pemeliharaan ataupun pengadaan kebutuhan. Hal paling sederhana adanya administrasi yang baik adalah adanya dokumentasi mengenai kegiatan-kegiatan sekolah, baik secara akademis maupun non akademis, misalkan buku besar siswa yang tersusun rapi, arsip- arsip kegiatan kesiswaan yang terdokumentasi dengan baik.

Jadi dari hasil penelitian maka dapat disimpulkan bahwa peran administrator telah dijalankan oleh kepala sekolah PAUD Terpadu Pratiwi. Walaupun pada kenyataannya fungsi tersebut diteruskan pelaksanaanya oleh wakil yang terpilih, namun 
tetap di bawah pengawasan dan pengarahan kepala PAUD Terpadu Pratiwi. Lebih lanjut dengan adanya administrasi yang baik maka dapat diinventarisis dengan mudah kelemahan dan kekuatan dari PAUD Terpadu Pratiwi, sehingga hal tersebut dimungkinkan mampu mempermudah peningkatan kualitas pendidikan dengan penyusunan strategi yang tepat dan akurat berdasarkan ineventarisir masalah dan kendala.

Pengawas (supervisor) secara akademik bisa bersifat formal dan informal. Pengawas formal adalah pengawas yang diangkat oleh dinas pendidikan tingkat provinsi, kabupaten, dan tingkat kecamatan berasal dari luar sekolah. Pengawas informal adalah pengawas yang bersal dari dalam sekolah sendiri, yaitu kepala sekolah, wakil kepala sekolah, para ketua unit, dan para guru bidang studi yang sudah senior (Pidarta, 2012:62).

Berkaitan dengan hal tersebut kepala sekolah PAUD Terpadu Pratiwi melakukan supervisi di bidang perencanaan, pelaksanaan dan evaluasi belajar mengajar. Selanjutnya kepala sekolah memberikan rekomendasi terhadap hasil pengawasan tersebut, mana yang perlu ditingkatkan mana yang perlu dipertahankan dan mana yang perlu di tinggalkan demi kemajuan pendidikan di PAUD Terpadu Pratiwi. Sifat supervisi yang dapat disimpulkan dari penelitian ini adalah supervisi yang bersifat konsultatif dimana kepala sekolah memberikan rekomendasi sebagai bentuk keterbukaan dan dorongan untuk maju.

Dari pengertian diatas dapat difahami bahwa prinsip supervisi kepala sekolah dilaksanakan berdasarkan pada kebutuhan guru dalam mengembangkan kemampuannya, dilaksanakan secara demokratis juga tidak kaku, namun bisa bersifat konsultatif dua arah dengan harapan adanya perbaikan dalam mutu kegiatan belajar mengajar. Jadi dapat disimpulkan bahwa kepala sekolah PAUD Terpadu Pratiwi telah melaksanakan fungsi supervisi dengan cukup baik.

Peran kepala sekolah debagai pemimpin dalam lembaga pendidikan adalah sebagai suatu usaha yang harus mampu mempengaruhi, mendorong dan menggerakan semua warga sekolah dalam upaya mencapai tujuan bersama.

Kepala Sekolah juga harus melakukan kerjasama dengan staf, memanfaatkan potensi staf untuk membantu merumuskan ide-ide baru dalam usaha meningkatkan mutu pendidikan. Komunikasi yang terbangun antara kepala sekolah sebagai pimpinan dan bawahannya harus terbangun secara dua arah sehingga terjadi suatu hubungan interaksi yang kondusif. Berkaitan dengan hal tersebut kepala sekolah PAUD Terpadu Pratiwi berdasarkan hasil penelitian telah melaksanakan fungsi kepeminpinanya dengan adanya pendelegasian tugas secara terstruktur dan juga hubungan baik yang antara kepala sekolah dan bawahannya. Hubungan yang kondusif dan professional tanpa mengesampingkan rasa kekeluargaan. Meski hal tersebut tidak lepas dari kendala yang timbul, dan dari hasil penelitian kebanyakan kendala timbul akibat adanya miss communication dan kurang jelasnya tugas yang didelegasikan.

Secara garis besar inovasi adalah suatu gagasan, kejadian, teknik-teknik, metode-metode, atau praktik yang diamati, disadari, dirasakan, diterima dan digunakan sebagai suatu hal yang baru oleh seseorang atau kelompok sebagai hasil diskoferi dan invensi. Dalam konteks sosial inovasi diberikan pengertian sebagai perubahan sosial yang digunakan untuk mencapai tujuan tertentu atau untuk memecahkan suatu masalah tertentu. Perubahan sosial tersebut dalamnya mencakup dimensi proses kreatif, adanya perubahan, mengarah kepada pembaharuan, dan memiliki nilai tambah.

Dalam inovasi atas kendala yang dihadapi oleh kepala sekolah PAUD Terpadu Pratiwi, dimana dari hasil penelitian menunjukan bahwa kendala yang dihadapi adalah masalah pembiayaan yang masih tidak mencukupi untuk membiayai program yang telah 
disusun. Selain itu dalam masalah peningkatan kualitas pendidikan, kepala sekolah melakukan inovasi dengan cara melibatkan partisipasi yang aktif dari orang tua murid untuk dapat berpatrtisipasi dalam mensukseskan pencapaian dan peningkatan mutu pendidikan.

Seorang kepala sekolah sebagai seorang motivator harus memiliki startegi yang tepat untuk memeberikan motivasi kepada para tenaga pendidik dalam melakukan berbagai tugas dan fungsinya.

Penataan lingkungan fisik, yaitu dalam hal ini ruang belajar, ruang guru dan prasarana lainnya akan memberi lingkungan kerja yang nyaman, dan hal tersebut membangkitkan timbulnya motivasi kerja. Selanjutnya suasana kerja yang menyenangkan, kerjasama yang kerap terjadi dan saling membantu juga mampu menimbulkan motivasi dalam menjalankan tugas dan fungsi para tenaga pendidikan yang ada di lingkungan sekolah. Kedisiplinan juga perlu diterapkan sebagai bentuk efesiensi dan efektifitas yang akan memotivasi produktifitas kerja, lebih lanjut diikuti dengan dorongan melalui perhatian dan bimbingan dan diberikan penghargaan sesuai dengan pencapaian yang dilakukan oleh para tenaga kependidikan. Dan hal tersebut ditujukan demi peningkatan kualitas pendidikan di PAUD Terpadu Pratiwi.

Hal ini sejalan denga apa yang dilaksanakan oleh kepala sekolah PAUD Terpadu Pratiwi yang dari hasil penelitian terlihat memberikan lingkungan kerja yang kondusif dan nyaman juga berusaha menegakan disiplin kerja yang tertuang dalam tugas pokok dan fungsi masing-masing bidang juga yang tertuang dalam tata tertib sekolah sebgai acuan kedisiplinan warga sekolah secara keseluruhan.selain itu adanya faktor motivasi yang berupa reward terhadap keberhasilan yang dicapai baik secara verbal maupun non verbal, baik secara moril maupun materil. Jadi dari hasil penelitian terlihat bahwa peranan motivator telah dijalan kan oleh kepala sekolah PAUD Terpadu Pratiwi.

Dari hasil penelitian yang dilakukan di PAUD Terpadu Pratiwi Kota Bangkinang tentang penerapan fungsi-fungsi kepemimpinan kepala sekolah, terdapat beberapa kelemahan-kelemahan walaupun pada dasarnya keseluruhan EMASLIM sudah baik. Kelemahan yang terlihat pada hasil penelitian tersebut terdapat pada beberapa fungsi yaitu. 1) Fungsi Administrator. 2) Fungsi Leader. 3) Fungsi Inovator. Sedangkan fungsi lainnya sudah tergolong berjalan sebagai mana mestinya.

\section{Fungsi Administrator.}

Kelemahan penerapan pada fungsi ini terlihat pada 'Pendelegasian hampir semua tugas Administrator kepada bawahan atau wakil yang di tunjuk'. Hal ini tentu kurang tepat mengingat penyelesaian segala administrasi belum tentu bisa diselesaikan oleh bawahan kepala sekolah tersebut karena banyak hal yang bawahan tidak tahu sementara hanya kepala ekolah yang tahu. Namun karena bawahan ada rasa takut maka pendelegasian tersebut diterima dengan penuh rasa was-was.

Upaya yang dilakukan kepala sekolah untuk mengurangi kelemahan tersebut diatas, dengan menunjuk satu orang wakil yang sangat dipercayainya dan merundingkan dengan wakil tersebut tentang beberapa hal mengenai Administrasi ini kiranya dapat ditangani dengan baik. Dengan memberikan kepercayaan tersebut dengan pendekatan persuasive dan tentu selalu memberikan pengawasan serta control yang baik, maka fungsi Administrator seorang kepala sekolah dapat terbantu dengan baik.

\section{Fungsi Leader.}

Kelemahan pada penerapan fungsi ini dari hasil penelitian dapat dilihat pada 'Adanya miss communication antar bawahan akibat dari kurang jelasnya tugas-tugas tambahan yang diberikan para wakil kepala sekolah kepada guru, seperti Pembina tari, 
Pembina menggambar dan lain-lain karena ditunjuk tidak dengan Surat Keputusan (SK)'.

Upaya yang dilakukan kepala sekolah PAUD Terpadu Pratiwi. PAUD Terpadu Pratiwi untuk mengurangi kelemahan miss communication tersebut, dengan mengadakan rapat yang dihadiri oleh seluaruh warga skeolah. Pada acara rapat dinas tersebut maka terungkaplah penyebab dari seringnya terjadi miss communication antara sesama guru.

\section{Fungsi Inovator.}

Kelemahan pada penerapan fungsi ini dapat dilihat pada 'Dana atau pembiayaan tidak mencukupi untuk membiayai program-program yang telah disusun seperti biaya honor pelatih tari, pelatih gambar dan lain sebagainya'.

Upaya yang dilakukan kepala PAUD Terpadu Pratiwi dalam menyikapi dan mengurangi kelemahan dana tersebut diatas dengan mengadakan pemanggilan orang tua siswa melalui komite sekolah. Pemanggilan orang tua siswa dilakukan pertingkat mulai kelas dalam pertemuan kepala sekolah, orang tua siswa dibicarakan bagaimana mengatasi kekurangan dana untuk mewujudkan program-program sekolah untuk mengakomodir kegiatan siswa, sehingga bakat dan prestasi siswa dapat berkembang sebagaimana mestinya. Pada kesempatan itu dapatlah kesimpulan bahwa orang tua mendukung kegiatan-kegiatan sekolah dijalankan sebagaimana mestinya, dan orang tua siswa mau memberikan bantuan bersipat subsidi silang yang jumlah tidak ditetapkan namun yang mampu boleh memberikan bantuan berapa saja sedangkan yang kurang mampu boleh menyumbang boleh juga tidak, dengan melaporkan kepada orang tua siswa berapa uang diterima sebagai sumbangan dan berapa uang keluar dengan menetapkan bendara dua orang dari pihak orang tua siswa tersebut.

\section{KESIMPULAN}

Simpulan yang dapat ditarik dari hasil penelitian berkenaan dengan fungsi EMASLIM kepala sekolah PAUD Terpadu Pratiwi adalah sebagai berikut :

1. Kepala sekolah PAUD Terpadu Pratiwi dalam menjalankan peran edukator berusaha menanamkan nilai-nilai mental, moral, fisik dan artistik dengan sistem keteladanan, kompetisi dan akomodasi tehadap seni dan budaya. Dalam hal ini kepala sekolah menjalankan peran educator dengan cara memberi keteladanan.

2. Sebagai seotang manajer Kepala PAUD Terpadu Pratiwi berusaha mengembangkan sumberdaya sesuai dengan potensinya melalui pengorganisasian yang terstruktur dan dijalankan melalui sistem pengawasan, pengarahan dan evaluasi dari kepala sekolah .

3. Sebagai seorang administrator Kepala PAUD Terpadu Pratiwi mendelegasikan tugas pengadministrasian terhadap wakil yang ditunjuk dengan tetap melakukan pengawasan dan pengarahan dengan penuh tanggung jawab.

4. Sebagai seorang supervisor, Kepala PAUD Terpadu Pratiwi melakukan super visi pendidikan meliputi perencanaan pelaksanaan dan evaluasi kegiatan belajar mengajar, yang bersifat konsultatif, juga mengikut sertakan guru dalam pelatihan, penyerapan metode pengajaran baru juga menetapkan target kelulusans siswa yang harus dicapai.

5. Sebagai seorang leader, Kepala PAUD Terpadu Pratiwi berusaha menerapkan kepemimpinan yang perofesional didasarkan pada kecerdasan emosional dan intelektual.

6. Sebagai seorang innovator Kepala PAUD Terpadu Pratiwi berusaha memberikana solusi pada permasalah yang dihadapi dalam pelaksanaan dan pencapaian target dari programa sekolah.

Aulad : Journal on Early Childhood, 2019, 2(1), 9 - 17 
7. Sebagai seorang motivator Kepala PAUD Terpadu Pratiwi berusaha membangun lingkungan kerja yang kondusif, menyenangkan dan memberikan penghargaan bagi prestasi yang didapat.

\section{DAFTAR PUSTAKA}

Danim, S. (2002). Visi baru manajemen sekolah. Jakarta: Bumi Aksara

Departemen Pendidikan dan Kebudayaan. 2001. Kamus Besar Bahasa Indonesia. Jakarta. Balai Pustaka

Departemen Pendidikan Nasional. 2001. Manajemen Peningkatan Mutu Berbasis Sekolah. Konsep dan Pelaksanaan, Jakarta: Direktor Pendidikan Menengah Umum. Depdiknas.

Departemen Pendidikan Nasional. 2001. Manajemen Peningkatan Mutu Berbasis Sekolah Buku 1. Konsep dan Pelaksanaan, Jakarta: Direktorat Pendidikan Menengah Umum. Depdiknas.

Marno dan Supriyatno. Triyo. 2008. Manajemen dan Kepemimpinan Pendidikan Islam. Bandung. PT Refika Aditama

Mulyasa. 2009. Menjadi Kepala Sekolah Profesional, Bandung: PT. Remaja Rosdakarya.

Nurkolis.2003. Manajemen Berbasis Sekolah, Teori Model dan Aplikasi. Jakarta. Gramedia Widiasarana

Pidarta, M. (2004). Pmanajemen Pendidikan Indonesia. Jakarta: Rineka Cipta.

Siagian. SP. 1995. Manajemen Stratejik. Jakarta. Bumi Aksara

Sugiyono, (2010), Metode Penelitian Administrasi, Bandung : Alfabeta.

Sugiyono. 2008. Metode Penelitian Kunatitatif Kualitatif dan R\&D. Bandung. Alfabeta.

Sukmadinata, Nana Syaodih. 2011. Metode Penelitian Pendidikan. Bandung: PT Remaja Rosdakarya

Wahjosamidjo (2011). Kepemimpinan Kepala Sekolah: Tinjauan Teoritik Dan Permasalahanya. Jakarta: Rajawali Press

Wahjosumidjo. 2001. Kepemimpinan Kepala Sekolah Tinjauan Teoritik dan Permasalahannya. Jakarta. Raja Grafindo

Zamroni. 2003. Paradigma Pendidikan Masa Depan. Yogyakarta. Bigraf Publishing 